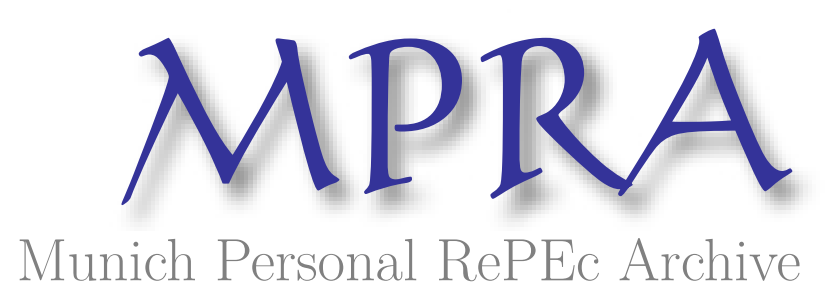

\title{
Corporate social responsibility in Islam
}

Elasrag, Hussein

April 2015

Online at https://mpra.ub.uni-muenchen.de/63670/

MPRA Paper No. 63670, posted 16 Apr 2015 14:32 UTC 


\section{Corporate social responsibility in Islam}

\section{Hussein Elasrag}

2014

\section{INTRODUCTION}

The difference between Islam and most other religions is that it did not content itself with merely establishing acts of worship and abandon the needs of society to a Caesar or any form of temporal governing body. Rather, Islam established ways of conduct, relationships, and rights and obligations for the individual vis-à-vis members of his family and the nation and for the nation vis-à-vis other nations. The reform of society was the main target of Islam. Even acts of worship contribute to the achieving of this reform. Within the framework of human society, the Islamic nation is a compact union having recourse to itself, possessing an inner sense of responsibility for its own members, and resisting decay, both individually and collectively.

This social solidarity (takaful) is apparent in all aspects of Prophet Muhammad's Message. The history of mankind shows that few societies have developed as strong a sense of solidarity or have cooperated as closely or acted as mercifully as have Islamic societies.Developing this two-way responsibility is Islam's principal way of achieving reform and social solidarity.The individual's responsibility for the community in Islamic societies and conversely the community's responsibility for the individual 
are of primary magnitude, constituting a trust of life and the highest of its responsibilities. It is for that reason that Islam introduced community worship. Islam also enjoins the group not to neglect the individual, obligating it to safeguard his various interests, to respect his rights and freedom, and to harmonize different interests. In Islam, praying in groups is preferred many times over to praying individually. The individual is thus an integral element of the Islamic society; he perfects it and is perfected by it, he gives to it and receives from it and he protects it, and is protected by it. Developing this two-way responsibility is Islam's principal way of achieving reform and social solidarity. Islam has impressed the meaning of these two types of responsibility on the individual and collective conscience in order to guarantee for Muslims the life of a unified, sound, happy, and productive body in a classless community. ${ }^{1}$

The value of social responsibility, either individually or collectively, has been recognised throughout history, and more structured programs for endowments and zakat were introduced by Islam in the 7th century. Major organisations throughout the world now realise that corporate social responsibility (CSR) is an important part of a company's operations, because of its positive impact on society, which in turn impacts positively on staff members and the general public. ${ }^{2}$

Corporate Social Responsibility (CSR) is a concept that has attracted worldwide attention and acquired a new resonance in the global economy. Heightened interest in CSR in recent years has stemmed from the advent of globalization and international trade 'which have reflected in increased business complexity and new demands for enhanced transparency and corporate citizenship. Moreover, while governments have traditionally assumed sole responsibility for the improvement of the living conditions of the population, society's needs have exceeded the capabilities of governments to fulfill them. In this context, the spotlight is increasingly turning to focus on the role of business in society and progressive companies are seeking to differentiate themselves through engagement in CSR.(Jamali \& Mirshak, 2007)

Corporate Social Responsibility CSR is an idea that has been constantly evolving as business firms are continually more aware of the community around them. CSR encompasses a business firm's obligation to society beyond simply maximizing its profits . CSR was not taken seriously and sometimes mocked by business firms before the late 1970s. The change in approach toward CSR can be partially attributed to the enactment of new

1 See : Abd al-Rahman Azzam ,Social Responsibility in Islam(Part One), in: http://www.onislam.net/english/shariah/hadith/this-hadith/456725-social-responsibility-in-islam1.html

${ }^{2}$ http://www.islamic-banking.com/csr.aspx 
legislation that created many of the regulatory government agencies during this time period. The new legislation provided business firms with an added incentive to earmark appropriate amounts of fiscal resources to CSR, rather than face harsh government regulation. The attitude toward CSR changed drastically by the late 1990s, as CSR was now a mainstream idea being promoted by different facets of society, ranging from corporations to governments.(Brown, 2013)

Corporate social responsibility (CSR) has grown enormously in the last thirty years and most business organizations feel to give in charity. The business organizations involving charitable giving and reflecting the highly competitive environment of the 1990s has been termed "strategic charity". It involves corporate giving which serves dual purposes: contributing funds to charitable causes while simultaneously benefiting the firm's financial bottom line and enhancing business political legitimacy. "Strategic charity" has become an accepted practice that allows a corporation to satisfy altruistic impulses to contribute in charitable causes while serving the bottom line. In this way the corporate community investment has emerged through the objectives of CSR programmes and business organizations some times take care of neighbor through its philanthropic responsibility programmes. Pure charity is concerned with assistance to education, arts and culture, health and social services, civic and community projects. While "strategic charity" combines pure philanthropy and business sponsorship with giving programmes that are directly or indirectly linked to business objectives. One of the characteristics of the "strategic charity" is a joint sponsorship of one or more corporations' programmes to implement through purposefully created charity foundations in order to optimize the charity value.(Hassan \& Latiff, 2009)

This responsibility is overwhelming and encompasses all aspects of a Muslim's life. It comprises a prescription towards positive (permissible and recommended) actions and a prescription against negative (impermissible and not recommended) actions. IFIs have generally ensured their operational status by avoiding negative actions. However, their approach to positive actions has been varied due to a lack of standards in the area.

The combination of these principles denotes a divine accountability for each Muslim to enjoin good and justice and forbid evil and injustice. These core principles therefore constitute the basis of individual social responsibility.

Milton Friedman is one of the architects of the movement against social responsibility, writing what is considered by many the seminal piece of work disparaging CSR and the businesses who promoting their CSR 
credentials.(Milton Friedman, 1962, 1982; Milton Friedman, September 13, 1970)

Friedman's objection to CSR was two-fold.(Moon, 2011) First, he argued that managers were accountable to the owners of the business and that,unless they otherwise signalled, the assumption should be that the owners wanted the

profits of the company to be maximised. The corollary is that for Friedman CSR is a net expenditure with no positive benefits for the company. Somewhat curiously, he added that it was possible for companies to make community investments but if these had some company advantages (e.g. workforce loyalty, productivity), they should not be considered as CSR. The conclusion here is that Friedman did not regard social and private Interests as potentially in conformance - rather they are dichotomous. This will betaken up later in the paper underthe heading, the 'socialisation of markets'.

Secondly, Friedman argued that CSR encroached on the proper terrain of (democratic) government and that managers are neither trained in addressing public policy questions and thus lack appropriate expertise, nor are they accountable for public policy issues. In both cases the contrast is made with legislators and public servants, both of whom he sees as having expertise and being properly accountable. In short, Friedman (1970) offers another dichotomy, in this case between the work of government and the business of business.

The business community needs to be aware of the responsibility it has towards the society. CSR does not mean just taking part in charitable activities and events, it means holding the responsibility to develop the society by envisioning future plans for socio-economic justice and be conscious about their responsibility for the welfare of society around them. The business community is highly qualified to set a plan for social change, and integrate their development goals with the country's at large, as well as engage with the other organisations on collaborative projects.

Islamic ethical principles provide a broader framework for CSR. In terms of responsibility and accountability, Muslims believe that they will be accounted for whatever they do in this world in the hereafter (life after death). In Islam, Muslims verily have to fulfill the will of Allah in order to seek the promised rewards in the hereafter. Thus, it requires that every deed and word in this world must be in line with the Islamic teachings. The importance of accountability to the man's life also has been manifested by the Prophet Muhammad (PBUH) as "each one of you is a guardian and 
each guardian is accountable to everything under his care". Individuals are expected to feel socially responsible for others in the community. In general, the aim of the Islamic economic system is to allow people to earn their living in a fair and profitable way on the basis of Shariah without exploitation of others, so that the whole society may get benefits. Islam also emphasizes the welfare of the community over individual rights. (Shamim \& Karim, 2010)

CSR in the world view of Islam requires both individuals and organisations to be guided in the development of a moral self that distinguishes between right and wrong and never loses sight of its responsibilities towards God and mankind. Islam as a religion has not lost its general influence on societies where it is practiced and constitutes a 'complete way of life' for the followers with specific implications for economic life and hence the role that responsible business can play in the development of a community/society/economy based upon the principles of social justice and equity rather than efficiency or profit generation. ${ }^{3}$

Over the past 50 years, business ethicists and management theorists have devoted much effort to thinking through the business-society relationship . These ethicists developed models that could be modified or compromised to suit evolving social interests. In general there are six major ethical models that now dominate ethical thinking leading to the concept of corporate social responsibility. These can be summarized as following: (Mohammed, 2007)

1. Relativism - Ethical decisions are made on the basis of self-interest and needs, excluding any interaction with or input from the outside.

2. Utilitarianism - Ethical decisions are made on the basis of calculating costs and benefits. Utilitarianism is generally considered outcome oriented. Whatever is good for majority is considered ethical.

3. Universalism - Ethical decisions stress on the intention of the decision or action (duty). Everyone under similar circumstances should reach similar decisions.

4. Rights - Ethical decisions stress a single value - liberty, and are based on individual rights (individual entitlement) ensuring freedom of choice.

5. Distributive Justice - Ethical decisions revolve around a single value justice. To be considered ethical, decisions and actions should ensure an equitable distribution of wealth and benefits (fairness and equality).

${ }^{3}$ http://www.islamic-banking.com/csr.aspx 
6. Eternal Law - Ethical decisions are made on the basis of eternal law, which is revealed in scripture.

These ethical models provide a background to the concept of corporate social responsibility. There have been efforts to conceptualise ethical behaviour in terms of business practices of corporations in society. Much of this work has specifically focused on theorizing what responsibility corporations have to society and what the consequences of related actions or inactions are.

CSR literature identifies several driving forces behind the growing trend towards CSR initiatives: (Wajdi Dusuki, 2008)

1. There is growing market pressure, wherein customers, employees, or capital markets exert some form of preference, pressure or signal. Social and ethical issue shave received increasing public attention and affected market performance, in addition to the traditional price and brand preferences. The growth of the ethical investment industry is another indicator of how much emphasis people are now apparently placing on the social and ethical behaviour of companies.

2. There has been an increasing regulatory pressure ranging from reporting requirements to government regulations that introduce compulsory business standards by which companies of all sizes have to abide.

3. Increased power of communications (e.g. internet, electronic media, and others) have driven consumers and pressure groups like social activists, non-governmental organizations (NGOs) and trade unions to scrutinize the activities of companies more effectively and develop strategies that may influence companies to act in a socially responsible way.

4. There is a competitive advantage that companies believe they can reap by being socially responsible. They foresee that by communicating effectively about their social, environmental and economic contributions, they can strengthen their brand, enhance their corporate reputation with customers and suppliers, and attract and retain a committed and skilled workforce. Indeed, extant literature asserts that, the commitment to CSR will in turn lead to better performance in terms of profitability, competitiveness and risk management.

The influence of Islam on business practices are well documented in the Holy Qur'an and Sunah, which are the main sources of business ethics in Islam. Islamic business values such as justice, socio-economic measure, 
human well-being, honesty etc are considered as the core of CSR in Islam. Islamic financial Institutions (IFIs) are considered as having an ethical identity and they have different social and economic objectives since the foundation of their business is based on religion .(Ali Aribi \& Gopinath Arun, 2012; Haniffa \& Hudaib, 2007; Maali, Casson, \& Napier, 2006)

The general objective of IFIs is to contribute to the development of the economy within the boundary of Islam. Within the range of Shari'a (Islamic law), IFIs are expected to be guided by an Islamic economic worldview, which is based on the principle of social justice and the wellbeing of society.(Wajdi Dusuki, 2008)

Islamic Financial Institution (IFI) are like any other conventional financial institution, which acts as an intermediary between providers of funds and fund users, the only difference being that the transactions and contracts of an IFI must comply with Islamic law.

Growing awareness of and demand for investing in accordance with Islamic ethical principles on a global scale have been catalyst towards making the Islamic banking and financial system as a flourishing industry. This is also a reflection of increasing wealth and capacity of investors, both Muslim and non-Muslim, to seek and invest in new investment products that serves their needs. The Islamic financial institutions (IFIs) earn profits as the other business firms earn profits. Many people say that IFIs should have involved "strategic charity" activities. Business of IFIs including Islamic banks is based on Shari'ah principles which need the IFIs to operate with the commitment of social responsibility.(Hassan \& Latiff, 2009)

In the context of IFIs, the Association of Accounting and Auditing Organization for Islamic Financial Institutions (AAOIFI) has issued specific standards on CSR known as Governance Standards No. 7: Corporate Social Responsibility, Conduct and Disclosure for IFIs. According to the (AAOIFI), Corporate Social Responsibility (CSR) for IFIs refers to all activities carried out by an $\mathrm{IFI}^{4}$ to fulfill its religious, economic, legal, ethical and discretionary responsibilities as financial intermediaries for individuals and institutions. Religious responsibility refers to the overarching obligation of IFIs to obey the laws of Islam in all its dealings and operations. Economic responsibility refers to the obligation for Islamic banks to be financially viable, profitable and efficient. Legal responsibility refers to the obligation of IFIs to respect and obey the laws and regulations of the country of operation. Ethical responsibility refers to the obligation of IFIs to respect the mass of societal, religious and

\footnotetext{
${ }^{4}$ The IFIs referred to any institution that plays the role of a financial intermediary that strictly abides by the provisions of the Shari'a. These include, but are not limited to Islamic banks and Islamic Insurance companies.
} 
customary norms which are not codified in law. Discretionary responsibility refers to the expectation from stakeholders that IFIs will perform a social role in implementing Islamic ideals over and above the religious, economic, legal and ethical responsibilities.(AAOIFI, n.d.)

Indeed, the founding fathers of modern day Islamic finance have concurred to the view that IFIs do have a heightened sense of social responsibility, as do any other 'Islamic' institution. However, this does not entail IFIs to become uncompetitive and unprofitable charitable organizations used to only further social development objectives. This entails a change in the mindset of Islamic bankers to incorporate social development objectives into their portfolio of investments profitably. As more investment account holders, shareholders and general stakeholders understand fully the objectives that underlie the Islamic economic system, there shall be more demand to know to what extent their local IFI fulfils those social objectives. Therefore, the IFI that extensively involves itself in CSR and demonstrates by disclosure that it is extensively involved in CSR will more easily earn the legitimacy of certain stakeholders (particularly those interested in the IFIs CSR activities), and ultimately earn their loyalty. This represents in itself a value proposition for IFIs who seek to retain clients on the basis of non-price competition. However, this is not to say that IFIs should implement corporate social responsibility because of its long term economic benefits. While viable economic institutions have to be driven by profit incentives, in the case of IFIs, it is not their only priority and certainly not the only reason for them to implement corporate social responsibility. Indeed, any notion that IFIs or any other institution that claims to be Islamic, for that matter, should be socially responsible must derive its justification from Islamic law and principles, as contained within the Qur'an and the Sunnah of the Prophet of Islam, Muhammad (P.B.U.H). Without this ultimate source of legitimacy, there is no reason for any action.(Farook 2007)

In the contemporary environment, business organizations have to face up to the task of meeting the expectations of a wide variety of their stakeholders. A 'stakeholder' is normally defined as someone that can be considered to have an interest (a stake), indirect or direct, in the company's operations. The UN defines 'stakeholder' as "any group or individual 
which is affected by the operations of the Company". Such stakeholders could be external like unions, consumers, suppliers, society, government, creditors, and shareholders or internal like employees, managers, and directors. Each category of stakeholders has a distinct interest and expectations from an organization. Owners (shareholders) expect an organization to maximize profits, the government expect organizations to meet their tax and legal obligations, management staffs also expected to meet performance and growth targets, non-managerial staff expects high rate of pay and job security. Trade unions expect to enjoy better working conditions and minimum wage requirements, customers expect organizations to offer value, quality, customer care and ethical products. Consumers are demanding more out of organizations than simply a quality product at a low price. Consumers expect organizations to demonstrate congruence with some social values as part of their contribution to the community. Creditors on their part expect organizations to have good credit scores, secure new contracts and have more liquidity and finally the local community from which organizations taps its resources expect the organizations to offer them jobs and take environmental issues seriously. Corporate organizations have to meet the expectations of each group of stakeholders without jeopardizing that of another stakeholder group. To meet these expectations with some reasonable degree of effectiveness, organizations are obliged to adopt a broader agenda which takes these diverse expectations into account. Nowadays, corporate organizations address these broad agenda by becoming socially responsible. Corporate Social Responsibility is thus increasingly adopted by organizations operating at national and international levels to address these varied stakeholder's expectations.(Shamim \& Karim, 2010)

\section{THE BASIS FOR ISLAMIC SOCIAL RESPONSIBILITY}

ICSR derives itself from core principles in the holy Qur'an. The three major foundational principles for ICSR are the vicegerency of mankind on earth, divine accountability and the duty on mankind to enjoin good and forbid evil.(Farook 2007)

According to

\section{A. Vicegerency}

The principle of vicegerency denotes that mankind is the representative of Allah on earth and as such Allah has entrusted mankind with stewardship of Allah's possession. 


\section{B. Divine Accountability}

The principle of divine accountability flows from the vicegerency principle and denotes that individuals will be accountable to Allah for all of their actions on the Day of Judgment. This principle is expounded in several verses of the holy Qur'an. This divine accountability is the basis for all actions of a Muslim, and in turn the representative organizations of Muslims.

\section{Enjoining Good and Forbidding Evil}

The principle of enjoining good and forbidding evil encapsulates the responsibilities that Allah places on Muslims as trustees and vicegerents.

Notions of corporate social responsibility (CSR) have been suggested to be consistent with an Islamic view of society. Indeed, values and principles that have been central to Islam since the time of the holy Prophet Mohammed (Peace and Blessings be upon him) may serve as a foundation for notions of corporate social responsibility (CSR) similar to those in the West. Much contemporary discussion of CSR, however, has not recognized this. These discussions have largely been based on a Western orientation informed by Western religious values. Moreover, CSR has evolved literally in response to particular issues or problems that are specific to businesses in a Western context. This led to a lack of a comprehensive global context within which a wider perspective of CSR should be positioned. On the other hand, the notion of social responsibility and justice has been an integral part of Islamic society for nearly 14 centuries. While Islamic philosophy is rich in precepts pertinent to CSR based on the Shariah (the Islamic legal and social system) derived from the Holy Qur'an and Hadith, these precepts have not yet been formally synthesized to present a systematic model with an explicit notion of CSR in Islam. ${ }^{5}$

Some of the key challenges going forward included:

- A significant barrier to the adoption of CSR frameworks in Muslimmajority nations (as well as other countries) is the fact that responsible companies will be competing with irresponsible ones. As one participant noted, "Responsible behavior should look like a

${ }^{5}$ http://www.islamic-banking.com/csr.aspx 
competitive advantage for companies, but the reality is that being responsible results in losing market share to an irresponsible competitor." How can responsible companies, governments and the local community stop the so-called "race to the bottom"?

- Who owns the responsibility? The responsibility to the community, the company, the economy? As more and more companies take on CSR activity and public-private partnerships,some participants questioned whether traditional roles of responsibility for social welfare are being abdicated and shifted, not just from the government to the private sector, but from the collective to the individual. Is this a good thing or a bad thing? Is this the formation of a new normal? Should it be?

- Participants considered whether CSR activities could be effectively scaled to create lasting impact and social change. If a particular CSR project is nothing more than a "drop in a bucket," can enough drops eventually fill the bucket? The answer to this question is dependent on the number of small and medium sized businesses that participate in CSR activities. How to get that segment of the economy to participate remains a significant challenge.

\section{References}

AAOIFI. (n.d.). Governance Standard for Islamic Financial Institutions No. 7 Corporate Social Responsibility Conduct and isclosure for Islamic Financial Institutions: Accounting and Auditing Organization For Islamic Financial Institutions (AAOIFI).

Ali Aribi, Z., \& Gopinath Arun, T. (2012). Corporate Social Responsibility in Islamic Financial Institutions (IFI): A Management Insight. Available at SSRN 2052635.

Brown, D. (2013). Corporate social responsibility. (A Senior Thesis submitted in partial fulfillment of the requirements for graduation in the Honors Program), Liberty University.

Farook , S. (2007). On corporate social responsibility of Islamic financial institutions. Islamic Economic Studies, 15(1), 3146.

Friedman, M. (1962, 1982). Capitalism and freedom. United States of America: University of Chicago press. 
Friedman, M. (September 13, 1970). The Social Responsibility of Business is to Increase its Profits. The New York Times Magazine.

Haniffa, R., \& Hudaib, M. (2007). Exploring the ethical identity of Islamic banks via communication in annual reports. Journal of Business Ethics, 76(1), 97-116.

Hassan, A., \& Latiff, S. B. A. (2009). Corporate social responsibility of Islamic financial institutions and businesses: Optimizing charity value. Humanomics, 25(3), 177-188.

Jamali, D., \& Mirshak, R. (2007). Corporate social responsibility (CSR): theory and practice in a developing country context. Journal of Business Ethics, 72(3), 243-262.

Maali, B., Casson, P., \& Napier, C. (2006). Social reporting by Islamic banks. Abacus, 42(2), 266-289.

Mohammed, J. A. (2007). Corporate social responsibility in Islam. Auckland University of Technology.

Moon, J. (2011). Corporate Social Responsibility. Manchester Business School.

Shamim, M., \& Karim, N. (2010). Corporate Social Responsibility: Contemporary Thought and Islamic Perspectives. Thoughts on Economics, 21(1), 45-66.

Wajdi Dusuki, A. (2008). What does Islam say about corporate social responsibility? Review of Islamic Economics, 12(1), 5-28.

UK Essays. Corporate Social Responsibility [Internet]. November 2013. [Accessed 10 July 2014]; Available from: http://www.ukessays.com/dissertations/sociology/corporate-socialresponsibility.php?cref $=1$.

UK Essays. Corporate Social Responsibility [Internet]. November 2013. [Accessed 10 July 2014]; Available from: http://www.ukessays.com/dissertations/management/corporate-socialresponsibility.php?cref $=1$.

Essays, UK. (November 2013). The Concept Of Corporate Social Responsibility Csr Shareholders Essay. Retrieved from http://www.ukessays.com/essays/business-stakeholders/the-concept-ofcorporate-social-responsibility-csr-shareholders-essay.php?cref=1 
